\title{
Effect of sires on wide scale of milk indicators in first calving Czech Fleckvieh cows
}

Oto Hanuš , Josef Kučera², Tao Yong ${ }^{3}$, Gustav Chládek², Radek Holásek ${ }^{4}$, Jiří Třináctý4, Václava Genčurová ${ }^{\text {and Kamila Sojková }}{ }^{4}$

${ }^{1}$ Research Institute For Cattle Breeding, Ltd., Rapotín, Czech Republic, ${ }^{2}$ Mendel's Agricultural and Silvicultural University, Brno, Czech Republic, ${ }^{3}$ Anhui Agricultural University, Hefei, China, ${ }^{4}$ Agriresearch Rapotín, Ltd., Czech Republic

\begin{abstract}
The possible genetic impact of sire on cattle populations, herd milk yield and milk traits (fat and protein) have been described in the literature along with its impact on some milk indicators (MIs) as somatic cell count, urea and ketones. There is a dearth of information on the impact on a series of other Mls (physical, chemical, health, technological). The goal of this study was to assess the possible effect of sire on a wide range of Mls including technological properties in Czech Fleckvieh to suggest future possible breeding trends. A series of Mls $(n=37)$ was investigated in individual milk samples (MSs). 191 effective daughters (MSs) were included. The sire groups $(n=13)$ were well balanced in terms of herd, lactation stage and sampling season. Only sires with $>5$ daughters were ranked. A linear model of analysis variance with the fixed effects, sire and combined factor (herd $\times$ year $\times$ season) was used. 19 Mls as log count of streptococci in fermentation ability of milk (log FAM-CS), FAM-CS, log total fine microflora count in FAM (log FAM-TCM), FAM-TCM, solids non fat (SNF), iodine content, citric acid (CA), titration acidity in FAM, lactose $(\mathrm{L})$, crude protein $(\mathrm{CP})$, true protein (TP), casein (CAS), dry matter, Mg and P content, milk alcohol stability, electrical conductivity (EC), titration acidity, casein numbers (for CP and TP), log count of lactobacilli in FAM (log FAM-CL), FAM-CL and $\mathrm{pH}$ in FAM were influenced by sire $(P<0.05)$. However SNF, CA, L, CAS and perhaps EC could be newly reflected as information for genetic improvement of dairy cattle with connection to dairy milk recovery and cow health. CA $\left(10.08 \pm 1.92 \mathrm{mmol} \mathrm{I}^{-1}\right)$ deserves special attention. The model variablity explanation moved from 6.97 (SCC) over $29.51(\mathrm{CA})$ to $48.32 \%(\mathrm{pH})$ for Mls. This is one of few studies to assess the impact of sire over a wide range of Mls and the results warrant careful evaluation and further study.
\end{abstract}

Keywords: sire, Fleckvieh, first calving cow, milk, composition indicators, casein, health indicators, citric acid, physical and technological properties, electrical conductivity, milk fermentation ability

\section{Zusammenfassung}

\section{Einfluss der Bullen auf eine breite Skala von Milchindikatoren bei erstkalbenden Töchtern des Tschechischen Fleckviehs}

Der mögliche genetische Bulleneinfluss auf die Milchleistung und Milchinhaltstoffe (Fett und Eiweiß) sowie Milchindikatoren wie somatische Zellzahl, Harnstoff oder Ketone 
wurden hinlänglich in der Literatur beschrieben. Über weitere chemische, physikalische, gesundheitliche oder technologische Milchindikatoren liegen weniger Informationen vor. Ziel vorliegender Untersuchung war die Prüfung des Vätereinflusses auf die letztgenannten Milchindikatoren beim Tschechischen Fleckvieh für die Gestaltung künftiger Zuchtziele. An individuellen Milchproben von 191 effektiven Töchtern wurden 37 Milchindikatoren erfasst. Die 13 einbezogenen Gruppen von Kühen waren hinsichtlich der Einflüsse Herde, Laktationsstadium und Jahreszeit der Probenname ausgeglichen. Bewertet wurden nur Bullen mit mehr als fünf Töchtern. Für die Varianzanalyse fand ein lineares Modell Anwendung welches neben den fixen Effekten Bulle die kombinierten Faktoren Herde, Jahr und Jahreszeit einschloss. Für folgende Milchindikatoren wurde ein signifikanter $(P<0,05)$ Bulleneinfluss nachgewiesen: Streptokokkenzahl (log FAM-CS), FAM-SC, Mikroflorazahl in der FAM (log FAM-TCM), FAM-TCM, fettfreie Trockensubstanz (SNF), Jodgehalt, Zitronensäuregehalt (CA), Titrationssäuregehalt in FAM, Laktosegehalt (L), Roheiweißgehalt, (CP), Reineiweißgehalt (TP), Kasein (CAS), Trockenmasse, Mg- und P-Gehalt, Milchalkoholstabilität, elektrische Leitfähigkeit EC), Tritationssäuregehalt (Milchsäurezahl), Kaseinzahlen für CP und TP, Laktobazilluszahl in der FAM (log FAM-CL), FAM-CL und $\mathrm{pH}$ in der Fam. Als neue Informationsquellen würden sich für eine züchterische Verbesserung der Milchkuhpopulation nur SNF, CA, L, CAS und evt. EC im Zusammenhang mit Milchqualität und Kuhgesundheit eignen. Der CA Wert $\left(10,08 \pm 1,92 \mathrm{mmol} \mathrm{I}^{-1}\right)$ muss gesondert betrachtet werden. Die Modellvariabilität der Milchindikatoren bewegte sich um Werte von 6.97 (SCC) über 29,51 (CA) bis 48,32 (pH). Die vorliegende Studie ist eine der wenigen welche den Bulleneinfluss auf eine Vielzahl von Milchindikatoren untersucht deshalb sind die Ergebnisse mit Bedacht zu bewerten und weitere Untersuchungen erforderlich.

Schlüsselwörter: Bulle, Fleckvieh, erstkalbende Kuh, Milch, Milchzusammensetzung, Kasein, Gesundheitsindikatoren, Zitronensäure, Milcheigenschaften physikalisch technologisch, elektrische Leitfähigkeit, Milchfermentationsfähigkeit

\section{Introduction}

Milk yield and milk composition (milk indicators, MIs), reproduction performance (Bezdíček et al. 2007, Parland et al. 2007), health status (Hinrichs et al. 2006) and other functional traits are important data for the genetic improvement of dairy cattle (Bergfeld \& Klunker 2002, Distl 2001). The genetic impact of sire on cattle populations, herd milk yields and some Mls have been desribed in a number of papers (Thompson et al. 2007a, 2007b, Biedermann et al. 2003, 2004, Bezdiček et al. 2008). These are usually called milk traits and most of the research has been carried out for such milk traits as milk fat and protein yield and percentage, dry matter (Schutz et al. 1990, Yazgan et al. 2010) and also somatic cell count (Schutz et al. 1990, Xu et al. 2006) as indicators of mammary gland health status. Some authors have also studied the effects of genetics on health and nutrition as Mls such as lactose, urea and ketones (Gravert et al. 1991, Wood et al. 2004, Miglior et al. 2006, Stoop et al. 2007). From a genetic point of view, there is still a dearth of information on a range of other important Mls. The goal of this 
study was therefore to assess the possible effects of sire on a wide range of important milk indicators including technological properties in Czech Fleckvieh to suggest a future possible trend in breeding work.

\section{Materials and methods}

\section{Animals and milk samples}

Individual milk sample (MSs) collection was carried out at five commercial dairy farms of the Czech Fleckvieh (CF) breed. Only the first calved dairy cows were sampled from 90 to 180 days in milk. The sampling period was two years and 191 MSs were collected. The dairy cows were kept in binding free stables with milking parlours and all were milked twice a day. The dairy cow nutrition was composed of TMR, which is typical for the country conditions and consisted of: maize silage; alfalfa silage; trifolium silage; whole spindle maize silage (LKS); brewery draff; alfalfa hay; concentrates. TMR and concentrates were fed according to milk yield and standard demands.

\section{Analyses of the individual milk samples}

The list of analyses is shown in Table 1 for 37 Mls. The analyses were carried out according to the following milk analytical procedures. The fat (F), $\mathrm{L}$ and SNF indicators were measured using MilkoScan 133B (Foss Electric, Denmark) calibrated according to reference method results (standard CSN 570536 and CSN 57 0530). The protein fractions CP, TP and CAS (N×6.38) were determined by Kjeldahl's method using the instrument line Tecator with Kjeltec Auto Distillation unit 2200 (Foss-Tecator AB, Sweden) according to CSN 57 0530. The macro- and microelement milk contents were investigated by atom absorption spectrophotometry using a Spectrometer SOLAAR S4 and 6F S97 Thermo Elemental (England). The SCC was determined using Fossomatic 90 instrument (Foss Electric, Denmark) according to CSN EN ISO 13366-2. The $U$ was determined by spectrophotometry at $420 \mathrm{~nm}$ wavelength. The specific reaction solution was prepared as a sour mixture with the $p$-dimethylaminobenzaldehyde (Hanuš et al. 1995) using Spekol 11 instrument (Carl Zeiss Jena, Germany). The AC was investigated by spectrophotometry at $485 \mathrm{~nm}$ wavelength. The AC was absorbed in alkali solution of $\mathrm{KCl}$ with salicylaldehyde after to 24 hours microdiffusion (O’Moore 1949, Vojtíšek 1986) using Spekol 11. The CA was determined by spectrophotometry at $428 \mathrm{~nm}$ wavelength. Milk was coagulated by trichloracetic acid and the adventitious filtrate then allowed to react with pyridine and acetanhydride $\left(30 \mathrm{~min}\right.$ at $32^{\circ} \mathrm{C}$ ). Used instrument was Spekol 11 (Hanuš et al. 2009). The MFP values were analysed using a top cryoscope Cryo-Star automatic Funke-Gerber (Germany) which was calibrated by standard $\mathrm{NaCl}$ solutions (Funke-Gerber). The EC was measured

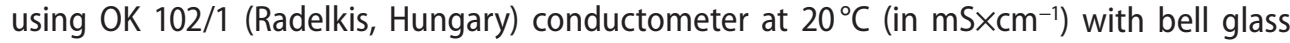
electrode which was calibrated by salt $(\mathrm{KCl})$ solution $\left(10.2 \mathrm{mS} \times \mathrm{cm}^{-1}\right)$. The active acidity $(\mathrm{pH})$ was measured using the $\mathrm{pH}$-meter CyberScan 510 (Eutech Instruments) which was calibrated by buffer solutions ( $\mathrm{pH} 4.0$ and 7.0$)$ at $20^{\circ} \mathrm{C}$. The TA was measured by milk titration $(100 \mathrm{ml})$ using alcaline solution according to CSN 57 0530. The AS was determined with the help of the milk titration $(5 \mathrm{ml})$ by $96 \%$ ethanol $(\mathrm{ml})$ to the creation of protein precipited flakes. The FAM-CL, -CS and -TCM (carried out according to standard ON 570534 by slightly modified 
procedure with thermophilic yoghurt culture YC-180-40-FLEX=Streptococcus thermophilus, Lactobacillus delbrueckii subsp. lactis and L. d. subsp. bulgaricus) were investigated by calculating of the colony forming units (CFU) using the classical plate cultivation method (at $30^{\circ} \mathrm{C}$ for $72 \mathrm{~h}$ ) with GTK M (Milcom Tabor) agar according to CSN ISO 6610.

Table 1

List of abbreviations of milk indicators (MIs) with their units

\begin{tabular}{|c|c|c|c|}
\hline Abbreviation & Milk indicator & Unit & Note \\
\hline $\mathrm{F}$ & fat & $\mathrm{g} \times 100 \mathrm{~g}^{-1} ; \%$ & \\
\hline L & lactose & $\mathrm{g} \times 100 \mathrm{~g}^{-1} ; \%$ & monohydrate \\
\hline $\mathrm{CP}$ & crude protein & $\mathrm{g} \times 100 \mathrm{~g}^{-1} ; \%$ & \\
\hline TP & true protein & $\mathrm{g} \times 100 \mathrm{~g}^{-1} ; \%$ & \\
\hline CAS & casein & $\mathrm{g} \times 100 \mathrm{~g}^{-1} ; \%$ & \\
\hline WP & whey protein & $\mathrm{g} \times 100 \mathrm{~g}^{-1} ; \%$ & \\
\hline NPN & non protein nitrogen matter & $\mathrm{g} \times 100 \mathrm{~g}^{-1} ; \%$ & \\
\hline URN & urea nitrogen ratio in NPN & $\%$ & \\
\hline SNF & solids non fat & $g \times 100 g^{-1} ; \%$ & \\
\hline DM & dry matter & $\mathrm{g} \times 100 \mathrm{~g}^{-1} ; \%$ & total solids \\
\hline $\mathrm{Ca}, \mathrm{P}, \mathrm{Na}, \mathrm{Mg}, \mathrm{K}$ & & $\mathrm{mg} \times \mathrm{kg}^{-1}$ & macroelements \\
\hline I & & $\mu g \times l^{-1}$ & microelement \\
\hline SCC & somatic cell count & thousand $\times \mathrm{ml}^{-1}$ & \\
\hline U & urea & $\mathrm{mg} \times 100 \mathrm{ml}^{-1}$ & \\
\hline$A C$ & acetone & $m g \times l^{-1}$ & \\
\hline CA & citric acid & $\mathrm{mmol} \times \mathrm{I}^{-1}$ & \\
\hline $\mathrm{F} / \mathrm{CP}$ & fat/crude protein ratio & & \\
\hline AS & alcohol stability & $\mathrm{ml}$ & thermostability replacement \\
\hline TA & titration acidity & $\mathrm{ml}$ & Soxhlet-Henkel \\
\hline EC & conductivity & $\mathrm{mS} \times \mathrm{cm}^{-1}$ & electrical conductivity \\
\hline $\mathrm{pH}$ & actual acidity & & \\
\hline MFP & milk freezing point & ${ }^{\circ} \mathrm{C}$ & \\
\hline CAS-CP & casein number & $\%$ & on CP basis \\
\hline CAS-TP & casein number & $\%$ & on TP basis \\
\hline RCT & cheeseability & second & rennet coagulation time \\
\hline CQ & cheeseability & class & curd cake quality \\
\hline $\mathrm{CF}$ & cheeseability & $\mathrm{cm}$ & cheese curd firmness \\
\hline WV & cheeseability & $\mathrm{ml}$ & whey volume \\
\hline FAM-T & fermentation ability & $\mathrm{ml}$ & milk yoghurt test \\
\hline FAM-pH & yog. actual acidity & & milk yoghurt test \\
\hline FAM-CL & lactobacilli count & $\mathrm{CFU} \times \mathrm{ml}^{-1}$ & yoghurt, colony forming unit \\
\hline FAM-CS & streptococci count & $\mathrm{CFU} \times \mathrm{ml}^{-1}$ & yoghurt, colony forming unit \\
\hline FAM-TCM & all microorganisms & $\mathrm{CFU} \times \mathrm{ml}^{-1}$ & fine fermenting microorg. \\
\hline FAM-RSL & ratio & & yog. streptococci/lactobacilli \\
\hline
\end{tabular}

TA: $\mathrm{ml} 0.25 \mathrm{~mol} \mathrm{l}^{-1} \mathrm{NaOH}$ solution for the titration of $100 \mathrm{ml}$ of milk (CSN 570530$), \quad$ AS: consumption of $96 \%$ ethanol in $\mathrm{ml}$ to protein coagulation in $5 \mathrm{ml}$ of milk, CQ: subjective estimation determined by inspection and touch from $1 \mathrm{st}$ (excellent) to 4th (poor) class, CF: depth of penetration of the corpuscle falling into curd cake in the standard way expresses the opposite relationship to firmness, WV: whey which was ejected during rennet curd cake creation for $60 \mathrm{~min}, \mathrm{FAM}-\mathrm{T}$ : with microbial culture (by titration acidity in $\mathrm{ml}$ of $0.25 \mathrm{~mol} \mathrm{I}^{-1} \mathrm{NaOH} \times 100 \mathrm{ml}^{-1}$ ); all the previous parameters at FAM were measured after the yoghurt test fermentation. 


\section{Design of the investigation and statistical procedures}

13 sires with more than five daughters were included in the data set for statistical evaluation. It means, 191 effective daughters (MSs) were included into investigation. The sire daughter result groups were well balanced in terms of herd, lactation stage and sampling season. Analysis of variance with fixed effects as sire and lactation stage was used for statistical evaluation of data set according to model as follows:

$$
y_{i j}=\mu+h y s_{i}+s_{j}+e_{i j}
$$

where $y$ is the investigated milkindicator, $\mu$ is the general average, hys is the herd $\times$ year $\times$ season effect (combined effect including the impact of herd, year of calving and season of calving) for $i$ from 1 to 6 combinations (this effect used for elimination of major part of systematic environmental variation), $s$ is the sire effect for $j$ from 1 to 13 (Figure 1) sires and $e$ is the random effect.

The SAS v9 programme package was used for the calculation. Means and GLM procedures were performed.

As the usual evaluation of milk yield traits was not main object of this evaluation fat and protein yields were not calculated and only fat and protein percentage were evaluated according to analytical results. The other milk indicators were the main goal of investigation. Therefore, SCC, AC and hygienic indicator values (FAM-CL, FAM-CS, FAM-TCM; Table 1) were logarithmically transformed (log) on a decimal basis because of lack of normal frequency distribution in most cases (Shook 1982, Reneau 1986, Meloun \& Militký 1994) and after that geometrical averages were also used in results evaluation. This data set had a smaller range than is usual for genetic evaluation of milk traits in the population. In contrast this result set was quite large in terms of evaluating such a wide spectrum of Mls which is not often case.

\section{Results and discussion}

\section{Main statistic characteristics of milk indicators}

The statistics for the Mls are shown in Table 2 . The means and variability are mostly very comparable to our previous results in CF (Hanuš et al. 2007) and not very different from results in Holstein (H) (Janů et al. 2007). Differences (compared to CF) are probably connected to first lactation effectshere for instance for $L$ and SNF contents which are markedly higher (5.11>4.96\% and $9.11>8.91 \%$; than CF results; Hanuš et al. 2007). Some differences (compared to $\mathrm{H})$ are probably connected, apart from to first lactation also with breed and milk yield ( $\mathrm{H}$ higher) effects for example especially for main protein fractions. The CP, TP and CAS contents are markedly higher for CF: $3.42>3.24 \% ; 3.23>3.07 \% ; 2.75>2.57 \%$ (compared to $\mathrm{H}$ results; Janů et al. 2007). 
Table 2

Main statistical characteristics of milk indicators in Czech Fleckvieh first calving dairy cows

\begin{tabular}{|c|c|c|c|c|c|}
\hline Variable & $\mathrm{n}$ & Mean & Standard deviation & Minimum & Maximum \\
\hline $\mathrm{F}$ & 191 & 3.91 & 0.548 & 2.28 & 5.67 \\
\hline $\mathrm{L}$ & 191 & 5.11 & 0.225 & 3.32 & 5.48 \\
\hline $\mathrm{CP}$ & 191 & 3.42 & 0.252 & 2.82 & 4.20 \\
\hline TP & 191 & 3.23 & 0.248 & 2.69 & 4.00 \\
\hline CAS & 191 & 2.75 & 0.247 & 1.81 & 3.40 \\
\hline WP & 191 & 0.48 & 0.099 & 0.28 & 1.11 \\
\hline NPN & 191 & 0.191 & 0.053 & 0.09 & 0.52 \\
\hline URN & 191 & 58.68 & 15.87 & 16.03 & 98.47 \\
\hline SNF & 191 & 9.11 & 0.325 & 7.70 & 9.83 \\
\hline DM & 191 & 13.02 & 0.681 & 10.62 & 14.82 \\
\hline $\mathrm{Ca}$ & 144 & 1340.6 & 199.1 & 803.0 & 1782.0 \\
\hline$P$ & 142 & 1178.3 & 166.1 & 824.0 & 1659.0 \\
\hline $\mathrm{Na}$ & 144 & 383.8 & 101.6 & 230.0 & 1100.0 \\
\hline $\mathrm{Mg}$ & 144 & 117.8 & 11.6 & 88.3 & 145.3 \\
\hline K & 144 & 1676.0 & 138.6 & 1183.0 & 1989.0 \\
\hline I & 120 & 333.1 & 124.8 & 116.0 & 690.0 \\
\hline SCC & 191 & 184 & 623 & 10 & 8011 \\
\hline $\log S C C$ & 191 & 1.90794 & 0.44366 & 1.0 & 3.90370 \\
\hline U & 191 & 36.63 & 6.40 & 20.87 & 53.86 \\
\hline AC & 191 & 3.47 & 3.03 & 0.01 & 31.69 \\
\hline $\log A C$ & 191 & 0.35306 & 0.55154 & -2.0 & 1.50090 \\
\hline CA & 144 & 10.08 & 1.92 & 4.55 & 14.91 \\
\hline $\mathrm{F} / \mathrm{CP}$ & 191 & 1.148 & 0.171 & 0.62 & 1.69 \\
\hline AS & 191 & 0.435 & 0.174 & 0.17 & 1.02 \\
\hline TA & 191 & 8.23 & 1.03 & 4.93 & 11.22 \\
\hline EC & 191 & 3.88 & 0.388 & 3.11 & 5.88 \\
\hline $\mathrm{pH}$ & 191 & 6.67 & 0.146 & 5.53 & 7.12 \\
\hline MFP & 191 & -0.52873 & 0.00731 & -0.54830 & -0.50980 \\
\hline CAS-CP & 191 & 80.41 & 3.09 & 59.15 & 86.54 \\
\hline CAS-TP & 191 & 85.18 & 3.111 & 61.99 & 90.48 \\
\hline RCT & 191 & 132.0 & 61.6 & 30.0 & 510.0 \\
\hline CQ & 191 & 2.31 & 1.029 & 1 & 4 \\
\hline $\mathrm{CF}$ & 191 & 1.77 & 0.167 & 0.5 & 2.0 \\
\hline WV & 191 & 33.32 & 3.179 & 13.0 & 40.0 \\
\hline FAM-T & 191 & 31.85 & 3.299 & 22.43 & 42.54 \\
\hline FAM-pH & 191 & 4.89 & 0.182 & 4.46 & 5.30 \\
\hline FAM-CL & 191 & 24623560 & 13539397 & 3600000 & 84000000 \\
\hline $\log F A M-C L$ & 191 & 7.32879 & 0.24036 & 6.55630 & 7.92430 \\
\hline FAM-CS & 191 & 643769634 & 206765642 & 200000000 & 1600000000 \\
\hline $\log F A M-C S$ & 191 & 8.78589 & 0.14517 & 8.30100 & 9.20410 \\
\hline FAM-TCM & 191 & 668393194 & 212821965 & 214000000 & 1642000000 \\
\hline log FAM-TCM & 191 & 8.80265 & 0.14344 & 8.33040 & 9.21540 \\
\hline FAM-RSL & 191 & 33.05 & 20.61 & 8.82 & 183.33 \\
\hline
\end{tabular}

Mean: arithmetical mean 


\section{Sire effects on milk indicators in general}

Statistic model efficiency and the significance of sire and combined effects for Mls are shown in Table 3. The model variablity explanation moved from 6.97 (SCC) over 29.51 (CA) to $48.32 \%$ $(\mathrm{pH})$ along individual Mls. According to evaluation of model determination coefficients and model significance and significance of both effects (sire and combined effect) it is possible to mark Mls which are important for interpretation of incidental sire impacts (Table 3, bold letters). The most important were L, CP, TP CAS, SNF, DM, P, Mg, I, CA, AS, TA, EC, CAS-CP, FAM-T, log FAM-CS and log FAM-TCM in this data set. There was a lower explanation of variability by model, no significant effect of sire and/ or too essential impact of combined effect (environmental conditions) for Mls. The model explained most of the variability for $\mathrm{pH}$, CF, log FAM-CS, log FAM-TCM, AC, SNF, I, CA and FAM-T but only at log FAM-CS, log FAMTCM, SNF, I, CA and FAM-T was this possible to explain by sire effect.

\section{Sire effects on main milk composition and nitrogen fraction indicators}

Fat content, which is normally included in genetic improvement programmes was not influenced by sire in this smaller data set, probably due to the greater variability of this MI. $\mathrm{CP}$, which is also normally included in genetic improvement, TP and CAS was significantly influenced by sire (Table 3). The most significant effect was at CAS (Figure 1,CAS), which could be newly routinely determined in dairy analytical systems (Broutin 2006 a; MIR-FT under certain circumstances) and in preference included in dairy herd improvement programmes. Lactose content as an indicator of udder health (Hanuš et al. 1993), which is connected with high milk yield (higher L; Janů et al. 2007, Hanuš et al. 2007) was influenced significantly by sire (Table 3). Miglior et al. (2006) reported marked difference between Ayrshire and $\mathrm{H}$ dairy cows (L 4.49 and $4.58 \%$; anhydride) in Canada, probably as a genetic factor. SNF and DM were also influenced by sire (Table 3). It was logically in links with protein fractions and L. 
Table 3

SAS GLM procedure results for milk indicators in terms of sire and combined (Com., herd $\times y$ year×season) effect in Czech Fleckvieh first calving dairy cows

\begin{tabular}{|c|c|c|c|c|c|c|c|}
\hline Variable & Model $\mathrm{R}^{2}$ & Model F & Model sign. & Sire F & Sire sign. & Com. F & Com. sign. \\
\hline $\mathrm{F}$ & 10.55 & 1.20 & 0.2684 & 1.31 & 0.2170 & 0.94 & 0.4565 \\
\hline L & 22.51 & 2.96 & 0.0002 & 2.85 & 0.0013 & 3.20 & 0.0086 \\
\hline CP & 19.76 & 2.51 & 0.0014 & 3.14 & 0.0005 & 0.98 & 0.4306 \\
\hline TP & 20.57 & 2.64 & 0.0008 & 3.48 & 0.0001 & 0.61 & 0.6927 \\
\hline CAS & 21.24 & 2.74 & 0.0005 & 3.84 & $<0.0001$ & 0.12 & 0.9866 \\
\hline WP & 11.97 & 1.38 & 0.1492 & 1.28 & 0.2365 & 1.64 & 0.1508 \\
\hline NPN & 10.22 & 1.16 & 0.3037 & 1.13 & 0.3366 & 1.22 & 0.3018 \\
\hline URN & 13.85 & 1.64 & 0.0598 & 1.75 & 0.0605 & 1.37 & 0.2394 \\
\hline SNF & 30.90 & 4.55 & $<0.0001$ & 6.16 & $<0.0001$ & 0.70 & 0.6259 \\
\hline DM & 17.44 & 2.15 & 0.0071 & 2.75 & 0.0019 & 0.71 & 0.6179 \\
\hline $\mathrm{Ca}$ & 10.33 & 0.86 & 0.6209 & 0.99 & 0.4667 & 0.56 & 0.7292 \\
\hline$P$ & 18.54 & 1.67 & 0.0563 & 2.03 & 0.0268 & 0.82 & 0.5382 \\
\hline $\mathrm{Na}$ & 18.65 & 1.71 & 0.0485 & 1.73 & 0.0671 & 1.66 & 0.1485 \\
\hline $\mathrm{Mg}$ & 25.32 & 2.53 & 0.0017 & 3.10 & 0.0007 & 1.17 & 0.3265 \\
\hline K & 17.12 & 1.54 & 0.0899 & 1.80 & 0.0546 & 0.93 & 0.4667 \\
\hline I & 30.85 & 2.70 & 0.0010 & 3.63 & 0.0002 & 0.49 & 0.7824 \\
\hline SCC & 6.97 & 0.76 & 0.7335 & 0.45 & 0.9428 & 1.53 & 0.1842 \\
\hline $\log S C C$ & 19.31 & 2.44 & 0.0020 & 1.58 & 0.1026 & 4.50 & 0.0007 \\
\hline U & 13.65 & 1.61 & 0.0665 & 1.78 & 0.0540 & 1.19 & 0.3179 \\
\hline$A C$ & 31.57 & 4.69 & $<0.0001$ & 1.60 & 0.0942 & 12.11 & $<0.0001$ \\
\hline $\log A C$ & 13.54 & 1.59 & 0.0701 & 1.08 & 0.3780 & 2.82 & 0.0177 \\
\hline$C A$ & 29.51 & 3.13 & 0.0001 & 3.79 & $<0.0001$ & 1.53 & 0.1848 \\
\hline $\mathrm{F} / \mathrm{CP}$ & 12.82 & 1.50 & 0.1007 & 1.61 & 0.0918 & 1.22 & 0.3034 \\
\hline AS & 21.29 & 2.75 & 0.0005 & 3.66 & $<0.0001$ & 0.59 & 0.7092 \\
\hline TA & 20.22 & 2.58 & 0.0010 & 2.87 & 0.0012 & 1.88 & 0.0994 \\
\hline EC & 27.80 & 3.92 & $<0.0001$ & 5.15 & $<0.0001$ & 0.96 & 0.4452 \\
\hline $\mathrm{pH}$ & 48.32 & 9.52 & $<0.0001$ & 1.63 & 0.0876 & 28.45 & $<0.0001$ \\
\hline MFP & 12.58 & 1.46 & 0.1131 & 1.45 & 0.1457 & 1.49 & 0.1969 \\
\hline CAS-CP & 16.59 & 2.02 & 0.0122 & 2.03 & 0.0244 & 2.02 & 0.0788 \\
\hline CAS-TP & 14.82 & 1.77 & 0.0351 & 2.01 & 0.0261 & 1.21 & 0.3088 \\
\hline RCT & 13.17 & 1.91 & 0.0283 & 1.64 & 0.0836 & 3.49 & 0.0325 \\
\hline CQ & 28.42 & 4.04 & $<0.0001$ & 1.28 & 0.2365 & 10.68 & $<0.0001$ \\
\hline CF & 34.00 & 5.24 & $<0.0001$ & 0.60 & 0.8385 & 16.38 & $<0.0001$ \\
\hline WV & 24.47 & 3.30 & $<0.0001$ & 1.40 & 0.1681 & 7.84 & $<0.0001$ \\
\hline FAM-T & 29.41 & 4.24 & $<0.0001$ & 4.69 & $<0.0001$ & 3.15 & 0.0096 \\
\hline FAM-pH & 18.00 & 2.23 & 0.0049 & 1.84 & 0.0452 & 3.18 & 0.0090 \\
\hline FAM-CL & 17.04 & 2.09 & 0.0092 & 2.61 & 0.0032 & 0.84 & 0.5226 \\
\hline $\log F A M-C L$ & 17.69 & 2.19 & 0.0060 & 2.49 & 0.0049 & 1.45 & 0.2093 \\
\hline FAM-CS & 25.35 & 3.46 & $<0.0001$ & 4.21 & $<0.0001$ & 1.63 & 0.1536 \\
\hline $\log F A M-C S$ & 31.72 & 4.73 & $<0.0001$ & 5.94 & $<0.0001$ & 1.82 & 0.1120 \\
\hline FAM-TCM & 25.94 & 3.56 & $<0.0001$ & 4.36 & $<0.0001$ & 1.66 & 0.1459 \\
\hline $\log$ FAM-TCM & 31.67 & 4.72 & $<0.0001$ & 5.93 & $<0.0001$ & 1.80 & 0.1155 \\
\hline FAM-RSL & 22.40 & 2.94 & 0.0002 & 1.65 & 0.0818 & 6.03 & $<0.0001$ \\
\hline
\end{tabular}

$\mathrm{R}^{2}$ : coefficient of determination, \%, sign.: statistical significance, F: fat value, bold letters in column variable mean important for interpretation in terms of sire effect, bold letters in columns $\mathrm{R}^{2}(>25 \%)$ and sign. mean the most important for interpretation; script letters in columns $\mathrm{R}^{2}(<15 \%)$ and sign. mean no important for interpretation. 


\section{CAS}

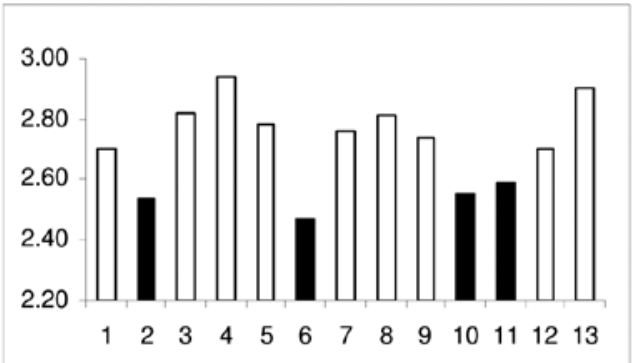

EC

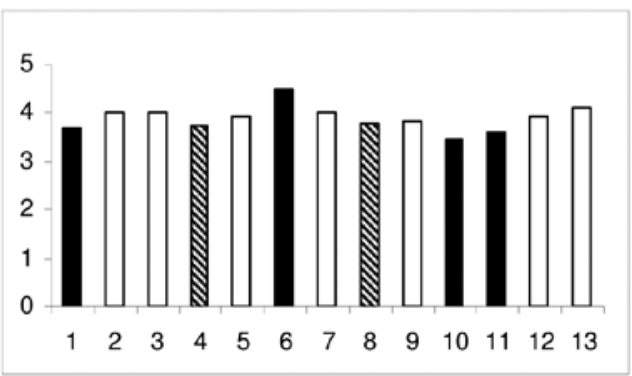

$\log$ FAM-CS

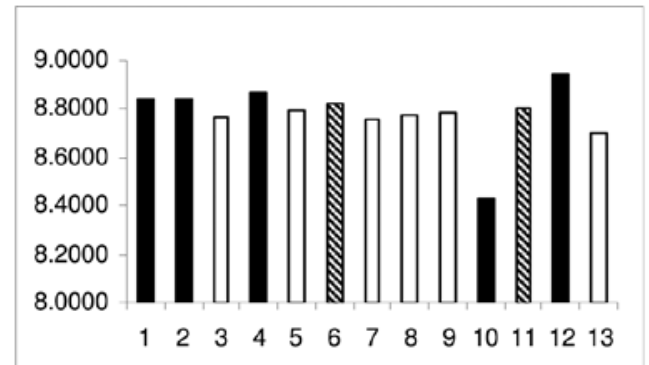

$\mathrm{CA}$

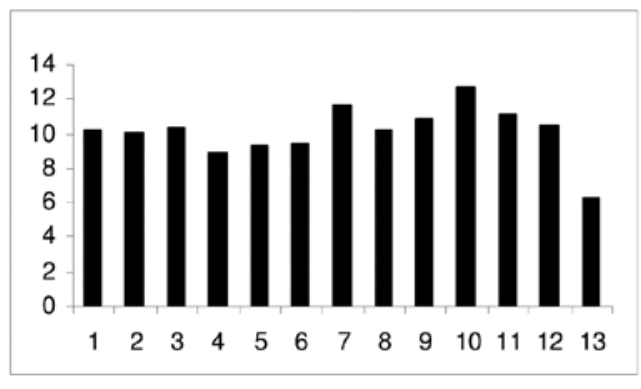

CAS-CP

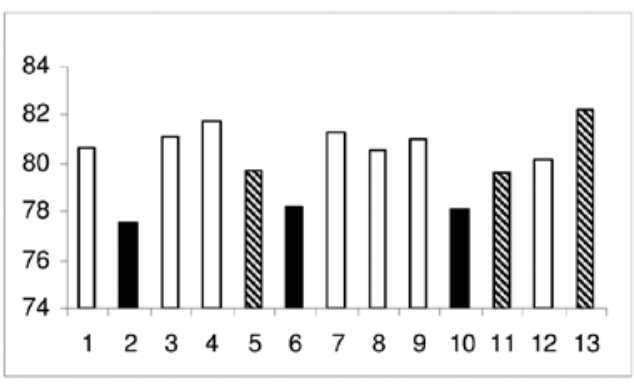

$\log$ FAM-TCM

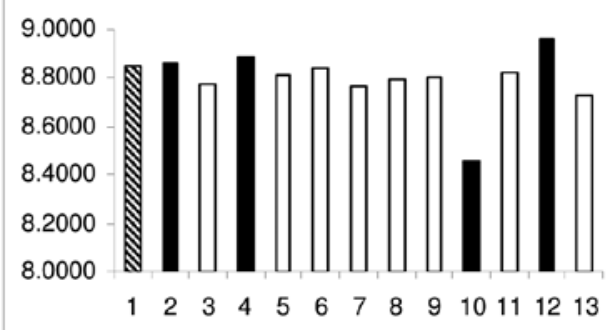

Sires: 1, HEL 8; 2, HG 109; 3, HG 141; 4, MKM 221; 5, MKM 229; 6, MOR 40; 7, MOR 45; 8, MOR 51; 9, MOR 59; 10, RAD 121; 11, RAD 64; 12, REZ 327; 13, UF 59. Columns: black $P<0.05$; dash $P<0.10$; empty $P>0.10$.

Figure 1

Graphical rendering of sire effects on selected milk indicators in Czech Fleckvieh first calving dairy cows

\section{Sire effects on some milk mineral components}

Microelement I and macroelements as Mg and P were significantly influenced by sire (Table 3) in this data set. Total $P$ is logically partly connected with casein fraction. Owing to high variability there could be a systematic interference effect caused by the presence (diffusion effect) and or absence of iodine from udder teat disinfection in daughters for I results (Table 2) in practice. $\mathrm{Mg}$ and I are minerals important to human nutrition from milk products in connection with nerve and overall metabolism. However in practical terms including these minerals into dairy cattle improvement is improbable. 


\section{Sire effect on dairy cow health state milk indicators}

SCC is a well-known indicator of mammary gland health in lactating mammals (Shook 1982, Reneau 1986, Amin 2001, Amin et al. 2002, Kühn et al. 2008). The geometric average of SCC was 81 thousand $\times \mathrm{ml}^{-1}$ (Table 2 ) and this confirmed that only relatively healthy dairy cows (clinical mastitis free) were used in this evaluation. In this paper the SCC was not influenced by sire effect (Table 3 ) although SCC is evaluated routinely in terms of mastitis resistance determination in dairy cattle populations, for instance as sire herd book values. Nevertheless, the coefficient heritability for somatic cell score was also low 0.1 (Schutz et al. 1990). The log $\mathrm{SCC}$ was influenced by combined environmental effect in this paper which is practically quite logical (Table 3).

Milk urea content is good indicator of nitrogen matter/energy metabolism in dairy cows (Larson et al. 1997, Panicke et al. 2000, Godden et al. 2001 a, 2001b, Mottram \& Masson 2001, Rajala-Schultz et al. 2001, Guo et al. 2004, Jílek et al. 2006, Miglior et al. 2006, Zhai et al. 2006, Stoop et al. 2007, Bezdíček et al. 2009, Řehák et al. 2009) mostly with negative relation to reproductive performance and longevity. Urea was not significantly influenced

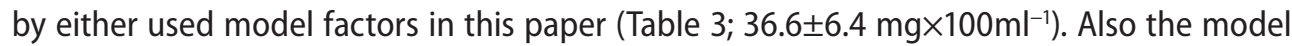
variability explanation was lower. Nevertheless, the sire effect was almost significant at alpha 0.05 ( $P=0.054$; Table 3 ). The possibility of including $U$ into routine milk recording and dairy cattle improvement in terms of nitrogen matter utilization from feeding rations could be a topic of further research. Miglior et al. (2006) mentioned lower milk $\mathrm{U}$ nitrogen in $\mathrm{H}$ dairy cows than Ayrshire $\left(11.11<12.20 \mathrm{mg} \times 100 \mathrm{ml}^{-1}\right)$. Lower $\mathrm{U}$ was found along with lower milk yield between breeds. This is in good accordance with previous results (Hanuš et al. 2007 and Janů et al. 2007), where $\mathrm{U}$ was lower in $\mathrm{H}$ breed than $\mathrm{CF}$ and also was lower along with lower milk yield within both breeds and between breeds. Also Godden et al. (2001 b) found a positive nonlinear association between milk urea and milk yield and energy corrected milk in Ontario $\mathrm{H}$ cattle. Stoop et al. (2007) reported milk U nitrogen heritability 0.14 , which is lower. Nevertheless, they allowed for the possibility of influencing urea by through genetic selection apart from herd practice.

Milk acetone was evaluated as a suitable indicator of animal energy metabolism. The higher AC the lower energy support or ketosis according to a number of authors (Gravert et al. 1986, 1991, Enjalbert et al. 2001, Mottram et al. 2002, Wood et al. 2004). AC was not influenced by sire in this data set although significance was quite close to set limits of probability

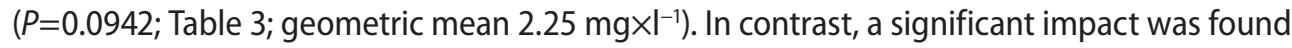
for combined environmental factor (Table 3). Nevertheless, Gravert et al. (1991) in cows with an increased $\mathrm{AC}$ in the first third of lactation $\left(0.25 \mathrm{mmol}^{-l^{-1}}\right)$ a negative correlation $(r=-0.47$ and -0.42 , resp.) to the energy quantity received through fodder and also to milk yield $(r=-0.30)$. They reported a heritability coefficient for milk AC 0.30 which was similar to the milk yield coefficient. Therefore, milk AC content was recommended as assessment of energy balance and to be included in milk recording and breeding value determination in terms of genetic control of energy nutrient utilization. Wood et al. (2004) reported heritability of AC less than $1 \%$, therefore they mentioned a genetic evaluation based on milk acetone recording on a monthly basis as having little use as a selection tool to decrease the incidence of ketosis.

Milk citric acid could be also a good indicator of animal energy metabolism (low CA means low energy maintenance) according to more papers (Khaled et al. 1999, Baticz et 
al. 2002, Garnsworthy et al. 2006, Kubešová et al. 2009). The lower milk CA the higher the energy deficiency and vice versa. The physiological range is between 8 and $10 \mathrm{mmol}^{-1}$. Garnsworthy et al. (2006) confirmed the hypothesis that variation in CA with stage of lactation was related to de novo synthesis of fatty acids and that the relationship was independent of diet and milk yield. This is promising for genetical possibilities. CA $\left(10.08 \pm 1.92 \mathrm{mmol}^{-1} \mathrm{l}^{-1}\right)$ was significantly influenced only by sire along good model variability explanation (Table 3 ). This is the most interesting result in this work (Figure 1, CA). The CA as an energy metabolism $\mathrm{MI}$ could be suitable for milk recording and dairy herd improvement as it is practical. This deserves special attention from the genetic evaluation point of view. Similarly metioned by Gravert et al. (1991) for milk acetone and control of feeding rations (energy nutrients) in dairy cows. Also routine series CA analyses are now accessible for effective milk laboratory work (Hanuš et al. 2009).

The F/CP ratio could be a suitable indicator of animal energy metabolism (Geishauser \& Ziebell 1995, Heuer et al. 1999, 2001). The higher the F/CP, the lower the metabolism energy support and possible ketosis. In contrast, a low F/CP ratio could provide information on low cow maintenance by structure fiber. F/CP ratio was not influenced by either sire or combined effect in this material.

\section{Sire effects on physical indicators}

Out of the physical Mls investigated the EC as a possible indicator of udder health (Hanuš et al. 1993) was statistic significantly influenced only by sire (Table 3, Figure 1, EC) and the model variability explanation was quite successful in this case. EC included into routine milk recording and dairy herd improvement is feasible. There is also a possibility of routine series measurements in dairy cow herds. The $\mathrm{pH}$ and MFP were not influenced by sire. However, $\mathrm{pH}$ was significantly influenced by combined environmental effect.

\section{Sire effects on milk technological properties}

Milk indicators as AS, TA, CAS-CP (Figure 1), CAS-TP, FAM-T, log FAM-CS (Figure 1), FAMCS, log FAM-TCM (Figure 1), FAM-TCM, log FAM-CL, FAM-CL and FAM-pH (Table 3) were influenced by sire significantly. This refers to almost all Mls of milk fermentation ability. The cheeseability indicators as RTC, CQ, CF and WV, which were significantly influenced by milk yield and differed between cattle breed (CF and H; Hanuš et al. 2007, Janů et al. 2007) were not influenced by sire in this data set (Table 3). On the other hand these were significantly influenced by combined effect.

This paper is one of few studies to assess sire impact over such wide range of Mls. Therefore the results for the technological properties need to be evaluated carefully. For example apropos fermentation ability, there are a number of interference interactions among milk components, properties and fine culture activities. Nevertheless, out including these technological properties in dairy cattle improvement is improbable in practice with the exception of AS and TA. However, their routine series determination is problematic. In conclusion 19 variables (Table 3) as log FAM-CS, FAM-CS, log FAM-TCM, FAM-TCM, SNF, I, CA, FAM-T, L, CP, TP, CAS, DM, Mg, P, AS, EC, TA, CAS-CP, CAS-TP, log FAM-CL, FAM-CL and FAM-pH from 37 Mls (Table 2) were significantly influenced by sire effect in this data set. 
Of these, only the SNF, CA, L, CAS and perhaps EC reflect new information for the genetic improvement of dairy cattle with connection to dairy milk recovery and cow health. Care is necessary in the results interpretation. Further studies are also necessary. Nevertheless, the importance of new genetic assessments for a whole series of Mls in terms of future cattle breeding work is currently increasing. This refers to rapid dissemination of modern effective technologies and milk analytical methods like NIR-FT and MIR-FT (near and mid infra-red spectrophotometry with Fourier's transformations) and other methods mostly on the basis of biosensors which are able to measure new Mls like casein, citric acid, urea, acetone (ketones), free fatty acids, milk freezing point and electrical conductivity with high efficiency (Koops et al. 1989, Hansen 1999, Heuer et al. 2000, Tsenkova et al. 2000, Kukačková et al. 2000, Broutin 2006 a, b, Mottram \& Masson 2001, Mottram et al. 2002, Jankovská \& Šustová 2003, Miglior et al. 2006, Roos et al. 2006, Bijgaart 2006, Šustová et al. 2007, Hanuš et al. 2008). These results could contribute to reliable data about milk indicators for official milk recording for possible inclusion into breeding and dairy cattle improvement. Possible trends were indicated in this paper. It could be used for next research trend in dairy cattle genetic improvement procedure.

\section{Acknowledgements}

This paper was supported by research projects ME 09081, MSM 2678846201 and NAZV, $1 \mathrm{G} 46086$ and by NRL-RM activities.

\section{References}

Amin AA (2001) Lactation and sample test-day multi-trait animal model for genetic evaluation of somatic cell scores in Hungarian Holstein Friesian crossbreeds. Arch Tierz 44, 263-275

Amin AA, Gere T, Kishk WH (2002) Genetic and environmental relationship among udder conformation traits and mastitis incidence in Holstein Friesian into two different environments. Arch Tierz 45, 129-138

Baticz O, Tömösközi S, Vida L (2002) Concentrations of citrate and ketone bodies in cow's raw milk. Periodica Polytechnica Ser Chem Eng 46, 93-104

Bergfeld U, Klunker M (2002) Importance of functional traits in cattle breeding and possibilities to improve by breeding. Arch Tierz 45, Special Issue, 60-67 [in German]

Bezdíček J, Hanuš O, Bjelka M, Dufek A, Jedelská R, Kopecký J (2009) Analyse of the relationship between milk components and reproduction in the Czech Fleckvieh first-calf cows. Acta univ agric et silvic Mendel Brun LVII, 1, 13-26

Bezdíček J, Šubrt J, Filipčík R (2008) Inbreeding depression of milk traits in Holstein cows in the Czech Republic. Arch Tierz 50, 415-425

Bezdíček J, Šubrt J, Filipčík R, Bjelka M, Dufek A (2007) The effects of inbreeding on service period and pregnancy length in Holsteins and Czech Fleckviehs after the first calving. Arch Tierz 50, 455-463

Biedermann G, Waldmann S, Maus F (2003) Genetic analysis of the population of Hinterwald cattle. Arch Tierz 46, 307-319 [in German]

Biedermann G, Ott B, Rübesam K, Maus F (2004) Genetic analysis of the population of Vorderwald cattle. Arch. Tierz. 47, 141-153 [in German]

van den Bijgaart HJCM (2006) New applications of mid-infra-red spectrometry for the analysis of milk and milk products. 2 Free fatty acids. IDF Bulletin, 406, 22-28

Broutin PJ (2006 a) New applications of mid-infra-red spectrometry for the analysis of milk and milk products. 1 Casein. IDF Bulletin, 406, 2-21 
Broutin PJ (2006 b) Use of highly accurate enzymatic method to evaluate the relationship between milk urea nitrogen and milk composition and yield on bulk and individual milk samples. 35th ICAR Session, Kuopio, Finland

CSN 57 0530: Methods for testing of milk and milk products. Standard CNI Prague, 1972 [in Czech]

CSN 57 0536: Determination of milk composition by mid-infrared analyser. Standard CNI Prague, 1999 [in Czech]

CSN EN ISO 13366-2 (57 0531): Milk - Enumeration of somatic cells - Part 2: Manual for control of fluoro-optoelectronic instrument. Standard CNI Prague, 2007 [in Czech]

CSN ISO 6610: Milk and milk products. Enumeration of colony-forming units of micro-organisms. Colonycount technique at $30^{\circ} \mathrm{C}$. Standard CNI Prague, 1996 [in Czech]

Distl O (2001) Implication of health traits in breeding of dairy cattle. Arch Tierz 44, 365-380 [in German]

Enjalbert F, Nicot MC, Bayourthe C, Moncoulon R (2001) Ketone bodies in milk and blood of dairy cows: Relationship between concentrations and utilization for detection of subclinical ketosis. J Dairy Sci 84, 583-589

Garnsworthy PC, Masson LL, Lock AL, Mottram TT (2006) Variation of milk citrate with stage of lactation and de novo fatty acid synthesis in dairy cows. J Dairy Sci 89, 1604-1612

Geishauser T, Ziebell KL (1995) The fat/protein ratio in the milk of cattle herds with the occurence of abomasal displacement. Dtsch Tierärztl Wschr 102, 469-494 [in German]

Godden SM, Kelton DF, Lissemore KD, Walton JS, Leslie KE, Lumsden JH (2001 a) Milk urea testing as a tool to monitor reproductive performance in Ontario dairy herds. J Dairy Sci 84, 1397-1406

Godden SM, Lissemore KD, Kelton DF, Leslie KE, Walton JS, Lumsden JH (2001 b) Factors associated with milk urea concentrations in Ontario dairy cows. J Dairy Sci 84, 107-114

Gravert HO, Jensen E, Hefazian H, Pabst K, Schulte-Coerne H (1991) Environmental and genetic effects on the acetone content in milk. Züchtungskunde 63, $42-50$ [in German]

Gravert HO, Langer R, Diekmann L, Pabst K, Schulte-Coerne H (1986) Ketone bodies in milk as indicators for energy balance in dairy cows. Züchtungskunde 58, 309-318 [in German]

Guo K, Russek-Cohen E, Varner MA, Kohn RA (2004) Effects of milk urea nitrogen and other factors on probability of conception of dairy cows. J Dairy Sci 87, 1878-1885

Hansen PW (1999) Screening of dairy cows for ketosis by use of infrared spectroscopy and multivariate calibration. J Dairy Sci 82, 2005-2010

Hanuš O, Frelich J, Janů L, Macek A, Zajiččková I, Genčurová V, Jedelská R (2007) Impact of different milk yields of cows on milk quality in Bohemian Spotted cattle. Acta Vet Brno 76, 563-571

Hanuš O, Gabriel B, Genčurová V, Žváčková I (1993) Lactose content in cow milk in the first third of lactation according to some indicators of secretion disorder of mammary gland. Živoč Výr/Czech J Anim Sci 38, 131138 [in Czech]

Hanuš O, Hulová I, Genčurová V, Štolc L, Kučera J, Kopecký J, Jedelská R, Motyčka Z (2009) Result interpretation of experimental calibration for milk citric acid determination via infrared spectroscopy (MIR-FT). Acta univ. agric. et silvic. Mendel Brun, ISSN 1211-8516, LVII, 77-101 [in Czech]

Hanuš O, Jílek M, Ficnar J, Beranová A, Jedelská R, Havlíčková K, Míčová Z (1995) Ways of preparing standards for calibration of indirect methods of determination of urea concentration in milk. Živoč Výr/Czech J Anim Sci 40, 441-451 [in Czech]

Hanuš O, Vegricht J, Frelich J, Macek A, Bjelka M, Louda F, Janů L (2008) Analyse of raw cow milk quality according to free fatty acids contents in the Czech Republic. Czech J Anim Sci 53, 17-30

Heuer C, Luinge HJ, Lutz ETG, Schukken YH, van der Maas JH, Wilmink H, Noordhuizen JPTM (2000) Determination of acetone in cow milk by Fourier transform infrared spectroscopy for the detection of subclinical ketosis. J Dairy Sci 83, 575-582

Heuer C, Schukken YH, Dobbelaar P (1999) Postpartum body condition score and results from the first test day milk as predictors of disease, fertility, yield, and culling in commercial dairy herds. J Dairy Sci 82, 295-304 
Heuer C, van Straalen WM, Schukken YH (2001) Prediction of energy balance in high yielding dairy cows with test-day information. J Dairy Sci 84, 471-481

Hinrichs D, Stamer E, Junge W, Kalm E (2006) Genetic analysis of several economically important disease traits in German Holstein cows. Arch Tierz 49, 209-221

Jankovská R, Šustová K (2003) Analysis of cow milk by near-infrared spectroscopy. Czech J Food Sci 21, 123-128

Janů L, Hanuš O, Frelich J, Macek A, Zajičková I, Genčurová V, Jedelská R (2007) Influences of different milk yields of Holstein cows on milk quality indicators in the Czech Republic. Acta Vet Brno 76, 553-561

Jílek F, Řehák D, Volek J, Štípková M, Němcová E, Fiedlerová M, Rajmon R, Švestková D (2006) Effect of herd, parity, stage of lactation and milk yield on urea concentration in milk. Czech J Anim Sci 51, 510-517

Khaled NF, Illek J, Gajdůšek S (1999) Interactions betweens nutrition, blood metabolic profile and milk composition in dairy goats. Acta Vet Brno 68, 253-258

Koops J, Kerkhof Mogot MF, van Hemert H (1989) Routine testing of farm tank milk by infra-red analysis. IV Prediction of the freezing-point depression from infra-red measurements and conductivity. Neth Milk Dairy J 43, 3-16

Kubešová M, Fajmon T, Frelich J, Trávníček J, Maršálek M (2009) Analysis of milk urea and milk citrate content during the postpartal period and their impact on reproduction in dairy cows. Výzkum v chovu skotu/Cattle Research LI, 185, 2-13

Kukačková O, Čurda L, Jindřich J (2000) Multivariate calibration of raw cow milk using NIR spectroscopy. Czech J Food Sci 18, 1-4

Kühn C, Reinhardt F, Schwerin M (2008) Marker assisted selection of heifers improved milk somatic cell count compared to selection on conventional pedigree breeding values. Arch Tierz 51, 23-32

Larson SF, Butler WR, Currie WB (1997) Reduced fertility associated with low progesterone postbreeding and increased milk urea nitrogen in lactating cows. J Dairy Sci 80, 1288-1295

Meloun M, Militký J (1994) Statistical evaluation of experimental data, 839 [in Czech]

Miglior F, Sewalem A, Jamrozik J, Lefebvre GM, Moore RK (2006) Analysis of milk urea nitrogen and lactose and their effect on longevity in Canadian dairy cattle. J Dairy Sci 89, 4886-4894

Mottram T, Masson L (2001) Dumb animals and smart machines: the implication of modern milking systems for integrated management of dairy cows. In: Integrated management system for livestock, occasional Publication 28, British Society of Animal Science, 77-84

Mottram T, Velasco-Garcia M, Berry P, Richards P, Ghesquiere J, Masson L (2002) Automatic on-line analysis of milk constituents (urea, ketones, enzymes and hormones) using biosensors. Comp Clin Path 11, 50-8

O'Moore LB (1949) A quantitative diffusion method for the detection of acetone in milk. Vet Rec 31, 457-458

ON 57 0534: Milk fermentationability determination. Standard Milk Industry Prague 1986 [in Czech]

Panicke L, Weingärtner J, Schmidt M, Krol T (2000) Relationship between lysosomal blood activity and milk contents of urea and protein in different phases of milk production in dairy cows. Arch Tierz 43, 17-25 [in German]

Parland McS, Kearney JF, Rath M, Berry DP (2007) Inbreeding effects on milk production, calving performance, fertility, and conformation in Irish Holstein-Friesians. J Dairy Sci 90, 4411-4419

Rajala-Schultz PJ, Saville WJA, Frazer GS, Wittu TE (2001) Association between milk urea nitrogen and fertility in Ohio dairy cows. J Dairy Sci 84, 482-489

Reneau JK (1986) Effective use of dairy herd improvement somatic cell counts in mastitis control. J Dairy Sci $69,1708-1720$

de Roos APW, van den Bijgaart HJCM, Horlyk J, de Jong G (2006) Screening for subclinical ketosis in dairy cattle by Fourier transform infrared spectrometry. Technical presentations, 35th ICAR Session, Kuopio, Finland, June, 53-59

Řehák D, Rajmon R, Kubešová M, Štípková M, Volek J, Jílek F (2009) Relationships between milk urea and production and fertility traits in Holstein dairy herds in the Czech Republic. Czech J Anim Sci 54, 193-200 
Shook GE (1982) Approaches to summarizing somatic cell count which improve interpretability. In: Nat. Mast. Council, Louisville, Kentucky, 1-17

Schutz MM, Hansen LB, Steuernagel GR, Reneau JK, Kuck AL (1990) Genetic parameters for somatic cells, protein, and fat in milk of Holsteins. J Dairy Sci 73, 494-502

Stoop WM, Bovenhuis H, van Arendonk JAM (2007) Genetic parameters for milk urea nitrogen in relation to milk production traits. J Dairy Sci 90, 1981-1986

Šustová K, Růžičková J, Kuchtík J (2007) Application of FT near spectroscopy for determination of true protein and casein in milk. Czech J Anim Sci 52, 284-291

Thompson JR, Everet RW, Hammerschmidt NL (2000b) Effects of inbreeding on production and survival in Holsteins. J Dairy Sci 83, 1856-1864

Thompson JR, Everet RW, Wolfe CW (2000a) Effects of inbreeding on production and survival in Jerseys. J Dairy Sci 83, 2131-2137

Tsenkova R, Atanassova S, Itoh K, Ozaki Y, Toyoda K (2000) Near infrared spectroscopy for biomonitoring: Cow milk composition measurement in a spectral region from 1,100 to 2,400 nanometers. J Anim Sci 78, 515-522

Vojtíšek B (1986) The determination of acetone in milk, colostrum, blood and urine of dairy cows by microdiffusion method. Veterinářství 36, 394-396 [in Czech]

Wood GM, Boettcher DF, Kelton DF, Jansen GB (2004) Phenotypic and genetic influences on test-day measures of acetone concentration in milk. J Dairy Sci 87, 1108-1114

Xu N, Paul S, Bennewitz J, Reinsch N, Thaller G, Reinhardt F, Kühn C, Schwerin M, Erhardt G, Weimann C, Thomsen H, Mishra S, Kalm E (2006) Confirmation of qualitative trait loci for somatic cell score on bovine chromosome 18 in the German Holstein. Arch Tierz 49, 111-119

Yazgan K, Makulska J, Weglarz A, Ptak E, Gierdziewicz M (2010) Genetic relationship between milk dry matter and other milk traits in extended lactations of Polish Holstein cows. Czech J Anim Sci 55, 91-104

Zhai SW, Liu JX, Wu YM, Ye JA, Xu YN (2006) Responses of milk urea nitrogen content to dietary crude protein level and degradability in lactating Holstein dairy cows. Czech J Anim Sci 51, 518-522

Received 19 October 2009, accepted 15 November 2010.

Corresponding author:

Oto Hanuš

email: oto.hanus@vuchs.cz

Research Institute for Cattle Breeding, Ltd., Výzkumníků 267, Rapotín, 78813 Vikýřovice, Czech Republic 